\title{
INTERMODALITY AND MULTILINGUAL RE-INSTANTIATION: JOINT CONSTRUCTION in Bilingual Genre Pedagogy
}

\author{
INTERMODALIDAD Y REINSTANCIACIÓN MULTILINGÜE: CONSTRUCCIÓN CONJUNTA \\ EN LA PEDAgOGÍA DE GÉNERO BILINGÜE \\ INTERMODALITÉ ET RÉ-INSTANCIATION MULTILINGUE : UNE CONSTRUCTION CONJOINTE \\ DANS LA PÉDAGOGIE DE GENRE BILINGUE
}

\author{
Harni Kartika-Ningsih \\ Ph. D. Linguistics, University of \\ Sydney, Australia. \\ Assistant Professor, Department of \\ Linguistics, Faculty of Humanities, \\ Universitas Indonesia, West Java, \\ Indonesia. \\ harni.kartika@ui.ac.id \\ https://orcid. \\ org/0000-0002-3658-7558

\section{David Rose} \\ Ph. D. Linguistics, University of \\ Sydney, Australia. \\ Honorary Associate, Linguistics, The \\ University of Sydney, NSW, Australia \\ david.rose@sydney.edu.au \\ https://orcid. \\ org/0000-0002-6630-6059
}

\begin{abstract}
This paper discusses the roles of intermodality and multilingualism in a genre pedagogy program aimed to improve students' literacy in Indonesia. It draws on data from an intervention program which extended the Reading to Learn (R2L) genre-based literacy pedagogy to embed English literacy learning in biology lessons for Indonesian junior high school students. This bilingual R2L program is innovative in that it involves the use of written and spoken Bahasa Indonesia and English for both teaching materials and instruction. This particular study focuses on the final stage of the program: The collaborative writing process known as joint construction. This is conducted in the bilingual R2L program by jointly making notes from Indonesian (L1) reading texts, jointly re-instantiating these notes as English (L2) lexis, and then using these L2 notes to jointly construct new L2 texts. The methodology is thus intermodal and multilingual, from written L1 texts, through oral dictation to L1 notes, then through bilingual discussion to re-instantiation as written L2 lexis, and finally through further bilingual discussion to re-instantiation as written L2 text. The study applies genre and register theory to closely examine classroom interactions in Joint Construction, from the perspectives of their structuring, the intermodal sourcing of meanings, and relations between teachers and learners. Evidence from student assessments suggest these designed applications of intermodality and multilingual reinstantiation are highly effective in the development of autonomous skills in L2 science writing. This article aims to describe how and why they are so effective.
\end{abstract}

Keywords: genre pedagogy; bilingual education; joint construction; EFL; Reading to Learn; intermodality; multilingualism.

\section{RESUMEN}

Este artículo analiza los roles de la intermodalidad y el multilingüismo en un programa basado en la pedagogía de género diseñado para mejorar la lectoescritura académica de los estudiantes en Indonesia. El presente estudio se basa en datos de un programa de intervención que adopta y extiende la pedagogía de género llamada Leer para Aprender (LPA), que en este caso incorporó lecciones de lectoescritura académica en el área de biología con el aprendizaje de inglés para estudiantes de educación básica secundaria en Indonesia. Este programa bilingüe

Received: 2020-09-11 / Accepted: 2020-10-16 / Published: 2021-

https://doi.org/10.17533/udea.ikala.v26n01a07 
de LPA es innovador en cuanto involucra el uso del idioma bahasa indonesio y el inglés oral y escrito, tanto para los materiales didácticos como para los ciclos pedagógicos. Este estudio en particular se centra en la etapa final del programa: el proceso de escritura colaborativa, conocido como construcción conjunta. En el programa bilingüe LPA aquí descrito, se lleva a cabo este proceso mediante la toma conjunta de notas de textos de lectura en Bahasa indonesio (L1), las cuales son reescritas de manera conjunta por los estudiantes y el profesor de inglés (L2), para luego ser usadas en la construcción conjunta de nuevos textos en L2. La metodología, por lo tanto, es intermodal y multilingüe, es decir, se empieza con textos escritos en L1, se sigue con el dictado oral hasta la construcción de notas en L1; y luego se pasa por la discusión bilingüe, hasta llegar a la reescritura de vocablos escritos en L2, para llegar finalmente a un nuevo texto escrito en L2, a través de una discusión bilingüe adicional. El estudio aplica la teoría de género y registro para analizar en detalle las interacciones en el aula, en la construcción conjunta desde las perspectivas de su estructuración, del origen intermodal de significados y de las relaciones entre profesores y alumnos. La evidencia de las evaluaciones de los estudiantes sugiere que estas aplicaciones de intermodalidad y reinstanciación multilingüe son muy efectivas en el desarrollo de habilidades autónomas en la escritura de textos en biología en L2. El presente artículo se propone describir el cómo y el porqué de su efectividad.

Palabras clave: pedagogía de género; educación bilingüe; construcción conjunta; inglés como lengua extranjera; Leer para Aprender; intermodalidad; multilingüismo.

\section{RÉSUMÉ}

Cet article examine les rôles de l'intermodalité et du multilinguisme dans un programme de pédagogie des genres visant à améliorer la littéracité des élèves en Indonésie. Il s'appuie sur les données d'un programme d'intervention qui a étendu la pédagogie d'alphabétisation basée sur le genre Reading to Learn/Lire pour Apprendre (R2L), pour intégrer l'apprentissage de l'alphabétisation en anglais dans des cours de biologie destinés aux élèves indonésiens du premier cycle du secondaire. Ce programme bilingue R2L est innovant en ce qu'il implique l'utilisation de l'indonésien et de l'anglais écrit et parlé pour le matériel pédagogique et l'instruction. Cette étude particulière se concentre sur la dernière étape du programme, le processus d'écriture collaborative connu sous le nom de construction conjointe. Ceci est réalisé dans le programme bilingue R2L en prenant ensemble des notes à partir de textes de lecture indonésiens (L1), en réecrivant ensemble ces notes en lexique anglais (L2), puis en utilisant ces notes en L2 pour construire ensemble de nouveaux textes L2. La méthodologie est donc intermodale et multilingue, depuis les textes écrits en L1, en passant par la dictée orale jusqu'aux notes en L1, puis en passant par la discussion bilingue jusqu'à la réinstanciation sous forme de lexis écrit L2, et enfin par la poursuite de la discussion bilingue jusqu'à la ré-instanciation sous forme de texte écrit L2. L'étude applique la théorie des genres et des registres pour examiner de près les interactions en classe dans la construction conjointe du point de vue de leur structuration, de l'approvisionnement intermodal des significations et des relations entre les enseignants et les apprenants. Les résultats des évaluations des étudiants suggèrent que ces applications conçues de l'intermodalité et de la réinstauration multilingue sont très efficaces dans le développement de compétences autonomes en rédaction scientifique L2. Cette étude vise à décrire comment et pourquoi ils sont si efficaces.

Mots-clés : pédagogie des genres ; éducation bilingue ; construction conjointe ; anglais langue étrangère ; lire pour apprendre ; intermodalité ; multilinguisme. 


\section{Introduction}

Over the past decade, the Reading to Learn literacy methodology (R2L) has gained popularity across the globe (e.g. Becerra et al., 2020; Coffin et al., 2013; Dell, 2011; Lucas et al., 2014; Millin, 2011; Ramírez, 2018; Shum et al., 2018). Like the Sydney School genre-based writing approach, which it incorporates, it applies the principle of "guidance through interaction in the context of shared experience" (Martin, 2000), but extends this to teaching reading as well as writing. It uses carefully designed teaching/learning interactions to enable every learner in a class to read challenging texts with comprehension, and then to apply what they have learned from reading to writing new texts.

R2L has inspired teaching practices in the Indonesian EFL context, extending the design as an $R 2 L$ bilingual program. The Sydney School genre-based approach to writing is now widely used in Indonesia, where it is known as GBA (Emilia, 2011). The R2L bilingual program began with a study investigating bilingual interactions in Indonesian classrooms using GBA (Kartika-Ningsih \& Rose, 2018). This research then led to an intervention program systematizing the use of L1 and L2 in teaching both reading and writing (Kartika-Ningsih, 2019). The R2L bilingual program follows the principles and practices of the Reading to Learn methodology (Rose, 2020a, 2020b; Rose \& Martin, 2012), but it makes explicit and systematic use of two languages, Bahasa Indonesia and English, in spoken and written modes.

This paper discusses how joint construction is carried out in the R2L bilingual program. In particular, it focuses on intermodality and multilingual re-instantiation, which shaped the design of the program. Intermodality describes the play of language between reading texts, note-making, and writing new texts, mediated by spoken interactions; multilingual re-instantiation refers to activities that re-instantiate meanings in one language to another, particularly from L1 to L2 during notemaking and text writing activities.
The data were drawn from video records of the R2L bilingual program implementation in two EFL classrooms from two different schools in Bandung, West Java, Indonesia. Both were large classes with 33 and 38 students each. Genre pedagogy has been part of the Indonesian curriculum, particularly subject English (Kartika-Ningsih \& Gunawan, 2019; Emilia, 2011) so teachers and students involved in the program were familiar with the notion of text types and the stages. The participants were Year 8 (13-14 years old) students who studied subject English at the time of the program. The students and the teacher were multilingual in that they spoke Bahasa Indonesia (the national language used throughout the schooling years and beyond), Sundanese (the regional language taught at school and used in the everyday domain), and English (learned as a compulsory subject).

\section{Theoretical Framework}

R2L, and genre pedagogy more generally, apply a model of meaning making developed in the research tradition of systemic functional linguistics (SFL). In the model proposed by Martin (1992), following Halliday \& Hasan (1976), the basic unit of meaning is a text. A text is an instance of actual meanings drawn from the reservoir of potential meanings shared by members of a culture (Martin \& Rose, 2007). Culture is modelled most broadly as constellations of genres, or types of social activity recognized by speakers (Martin \& Rose, 2008). Genres weave together three dimensions of meaning: fields of social activity, tenor of social relations, and modes of meaning making (e.g. spoken, written, visual). Patterns of field, tenor and mode (collectively register), are realized as patterns of meaning in language, at three levels: as patterns of discourse across a text (Martin \& Rose, 2007), patterns of wordings in lexicogrammar (Halliday \& Matthiessen, 2014), and patterns of phonology in speech or graphology in writing (Halliday \& Greaves, 2008). So, a text is at once an instance of patterns in genre, register, discourse, grammar, and expression. 
These two dimensions of the model, of genre realized as register realized as language (realization), and of texts as instances of potential meanings at each level (instantiation), are crucial considerations for designing multimodal and multilingual language pedagogies. The third consideration is the differences amongst speakers and their language communities, or individuation. From the reservoir of potential meanings in a culture, social groups and their members draw differing repertoires. Reservoirs and repertoires differ but also overlap between cultures, communities and persons. Bridging these differences, using their commonalities, is the goal of the R2L bilingual program.

Figure 1 brings together these three dimensions of the model (after Martin, 2010). Realization is modelled as a set of nested circles, with genre realized as field, tenor and mode, realized as three metafunctions of language (ideational, interpersonal, textual). At each of these levels, systems of potential meanings are instantiated in texts, and cultures' reservoirs of meanings are distributed to the repertoires of speakers.

In the study reported here, curriculum goals included learning of both a scientific field and English language resources for writing about it. The particular field was classification of bird species and reading texts on this topic were written in Bahasa Indonesia and English. The goal was for learners to re-instantiate this knowledge as a written English text. In both cases, the genre was a descriptive report. The institutional function of this genre is to generalize features of the natural and social world by classifying and describing them, so it is organized with the obligatory stages of Classification and Description.

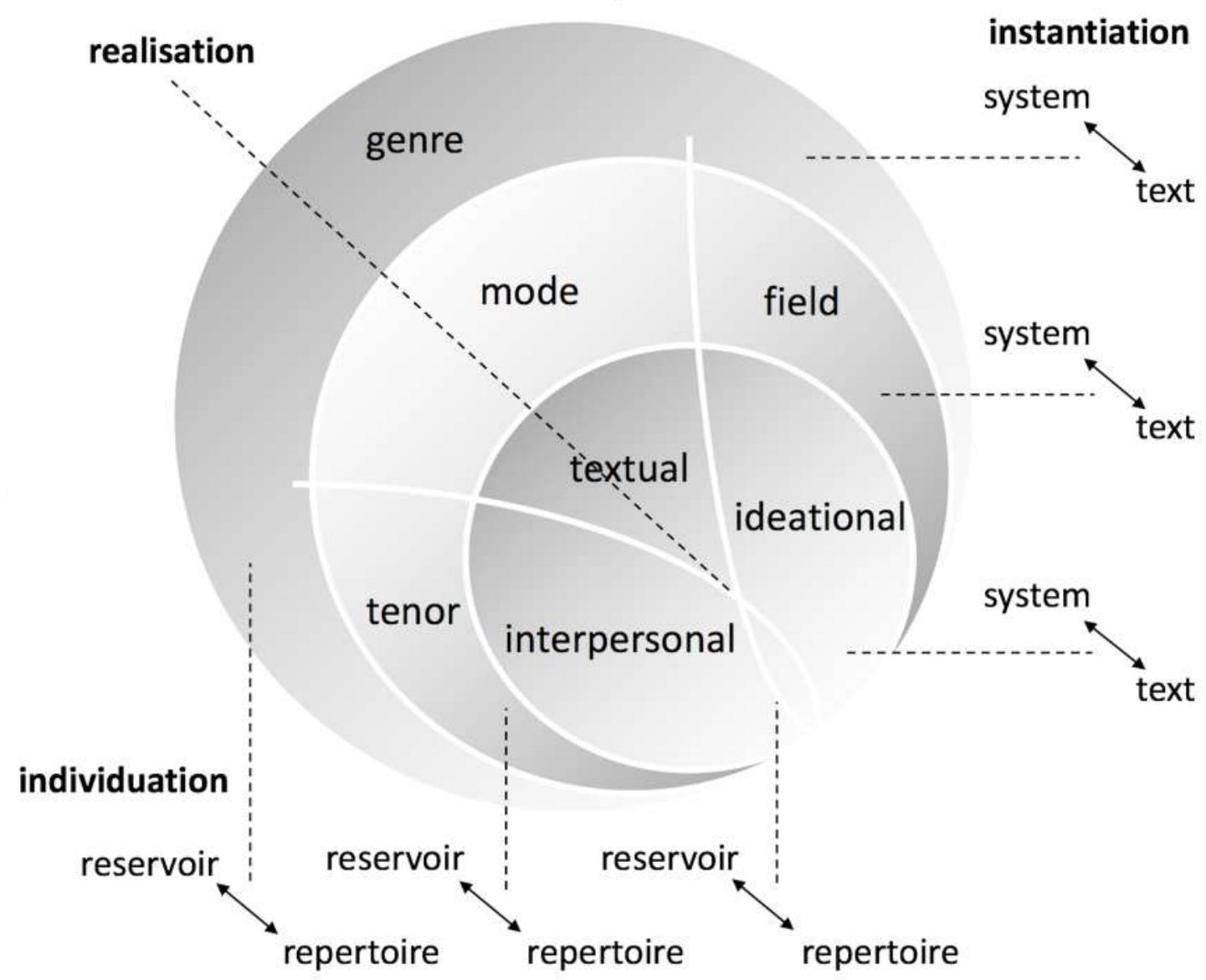

Figure 1 SFL model of meaning making 
The Description stage varies with the field being described. Reports on natural species typically have phases on appearance, behavior and habitat.

Hence, at the levels of genre and field, patterns of meaning in the Indonesian and English texts were similar, as they are equally concerned with the international activities of science ${ }^{1}$. As these levels of meaning are realized directly in patterns of discourse, these too were comparable between the L1 reading texts and L 2 target texts. In principle, once learners master reading and writing these patterns of genre, register and discourse in L1 texts, the difficulty of reading and writing the same genres and registers in L2 texts will be reduced. It is at the level of lexicogrammar that meaning resources differ most, not only between the languages, but between learners in the classes participating in the study. So a particular focus of the learning task was on re-instantiating patterns of genre, register and discourse, from the lexicogrammar of L1 to the lexicogrammar of $\mathrm{L} 2$.

\section{Curriculum Genres}

In the model, genres such as descriptive reports are termed knowledge genres, alongside stories, chronicles, explanations, procedures, arguments and text responses (Martin \& Rose, 2008). Knowledge genres configure fields of knowledge with social values, in spoken, written and often visual modes. In the classroom, knowledge and values are exchanged between teachers and learners in lessons. A lesson instantiates another family of genres known as curriculum genres. Curriculum genres configure two registers together: one is a curriculum register of knowledge and values; the other is a pedagogic register of learning activities and relations between teachers and learners, using spoken, written and visual modalities. In any lesson, or lesson series, a curriculum register of knowledge and values is exchanged between teachers and learners,

1 Patterns of genre and register in other genres, such as stories and arguments, may be quite different between Indonesian and European cultures. through a pedagogic register of activities, relations and modalities (Rose \& Martin, 2012). Figure 2 summarizes relations between these two registers.

Pedagogic activities are centered on learning tasks performed by learners. Learning tasks may be prepared and focused by teachers, who also usually evaluate them, and may elaborate on the learning. Learning tasks can be identified at three scales: of lessons and lesson series, of activities within each lesson, and of teacher/learner interactions, where the task is often to respond to teacher questions. This tier of pedagogic activity has been termed learning cycles, as it often involves cycles of focus questions, responses and evaluations (widely known as "initiation-response-feedback" or IRF cycles following Sinclair \& Coulthard, 1975).

Pedagogic relations are framed by the roles of teachers to present knowledge, evaluate learners and direct activities in classrooms, and the roles of learners to display or receive knowledge, and solicit knowledge and actions from teachers or peers. Pedagogic modalities are the sources of meanings (including teachers and learners' knowledge, recorded texts and images, and the environment) and the means of sourcing them into the classroom discourse, through speaking, gesturing, writing and drawing (Rose, 2018, 2020c).

\section{R2L Curriculum Genres}

In R2L, this model is deployed to design sequences of learning activities that provide maximal support for all learners to participate actively and acquire the knowledge of the curriculum. An R2L lesson series always begins with an activity known as Preparing for Reading. In this activity, the teacher reads a text aloud and discusses its general comprehension while learners follow. This may be followed by Detailed Reading, in which learners are guided to read a short text or extract, sentenceby-sentence. Detailed Reading involves carefully designed learning cycles, which prepare learners for the tasks of identifying series of wordings in sentences, whose meanings are then elaborated. 


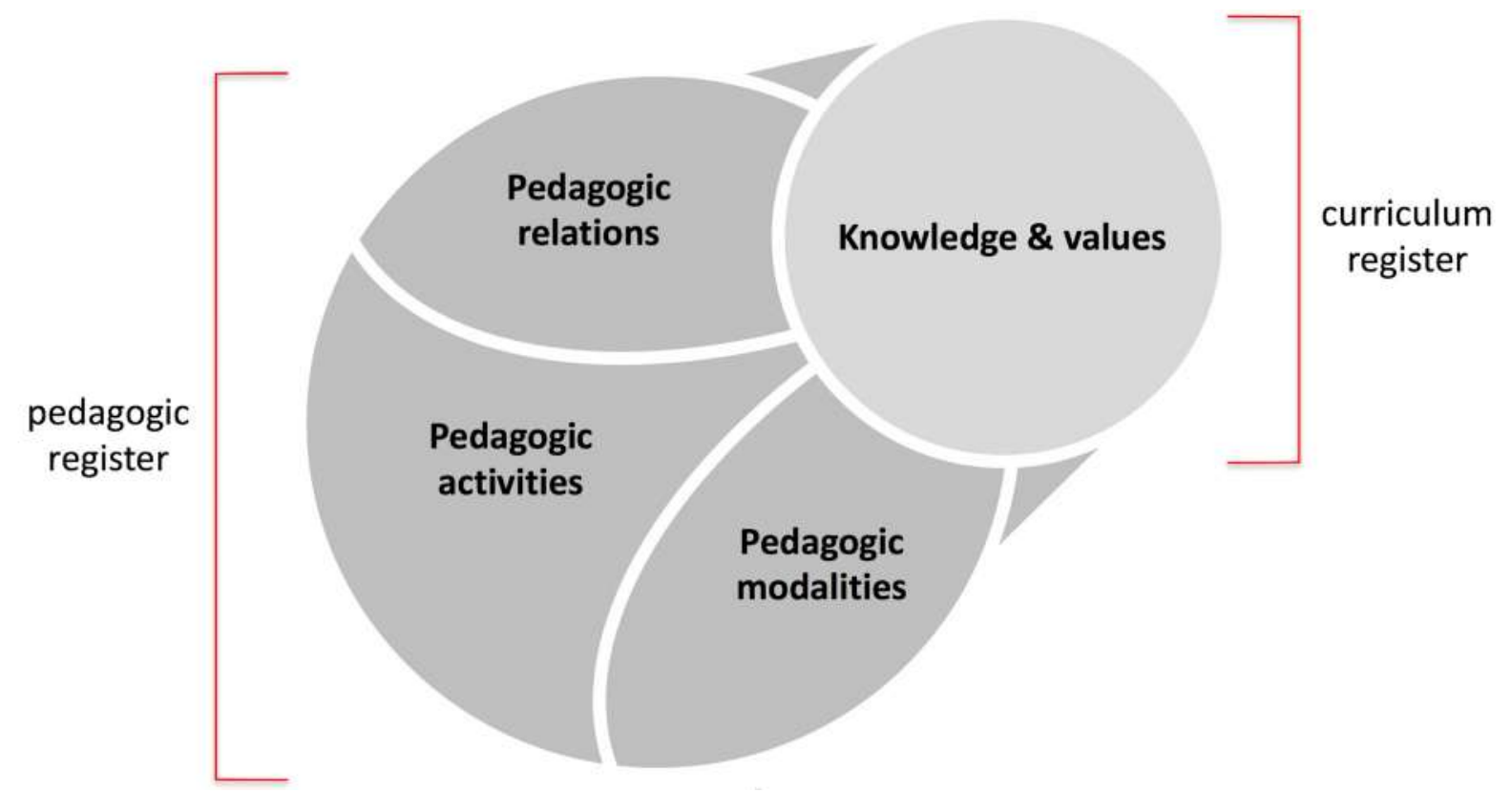

Figure 2 Curriculum Genres

Detailed Reading enables all learners in a class to read a passage of text with full comprehension, no matter what their initial independent reading abilities are (Rose \& Martin, 2012). It may be followed by intensive hands-on activities, called Sentence Making, Spelling and Sentence Writing, and/or by the activity of Joint Rewriting, in which learners are guided to use what they have learnt in Detailed Reading to write a new passage of text. An R2L lesson series typically ends with Joint Construction of a whole new text, using the knowledge about language and field learnt in the preceding activities, with the text structuring of a target genre. Crucially these are all learning activities, that are designed to give all students the resources they will need for independent writing tasks on which they may be evaluated.

This series of activities integrates learning of each level of language tasks, from genre and register, through discourse and grammar, down to graphology (spelling and lettering), and back up through these levels in writing activities. It naturally embeds literacy learning with learning curriculum fields, through closely reading and writing about them. This curriculum sequence, from whole text to text passage to words and back up again, is visualized as a "butterfly" in Figure 3 (after Rose, 2020b).

Figure 3 illustrates a common sequence of activities in R2L. Each of these activities are actually curriculum genres, in which pedagogic activities are designed to prepare learners for tasks of reading or writing. These curriculum genres are potential resources for teachers to design their own lesson series. The R2L bilingual program reported here used just the activities of Preparing for Reading, Detailed Reading, and Joint Construction. As the $\mathrm{L} 1$ reading texts and $\mathrm{L} 2$ target texts were quite short, the whole text could be read in detail, and could then be jointly constructed.

The central stage of each R2L curriculum genre is the task stage. In Preparing for Reading, this is the task of reading the text or following as it is read aloud. This task is prepared with an overview stage in which the field of the text is previewed with an oral discussion, often with visual supports, and its sequence of meanings is previewed. After reading it may be elaborated by reviewing key elements of its register. Detailed Reading is an iterative activity, in which the central task is to identify wordings in sentences. Each sentence is prepared 


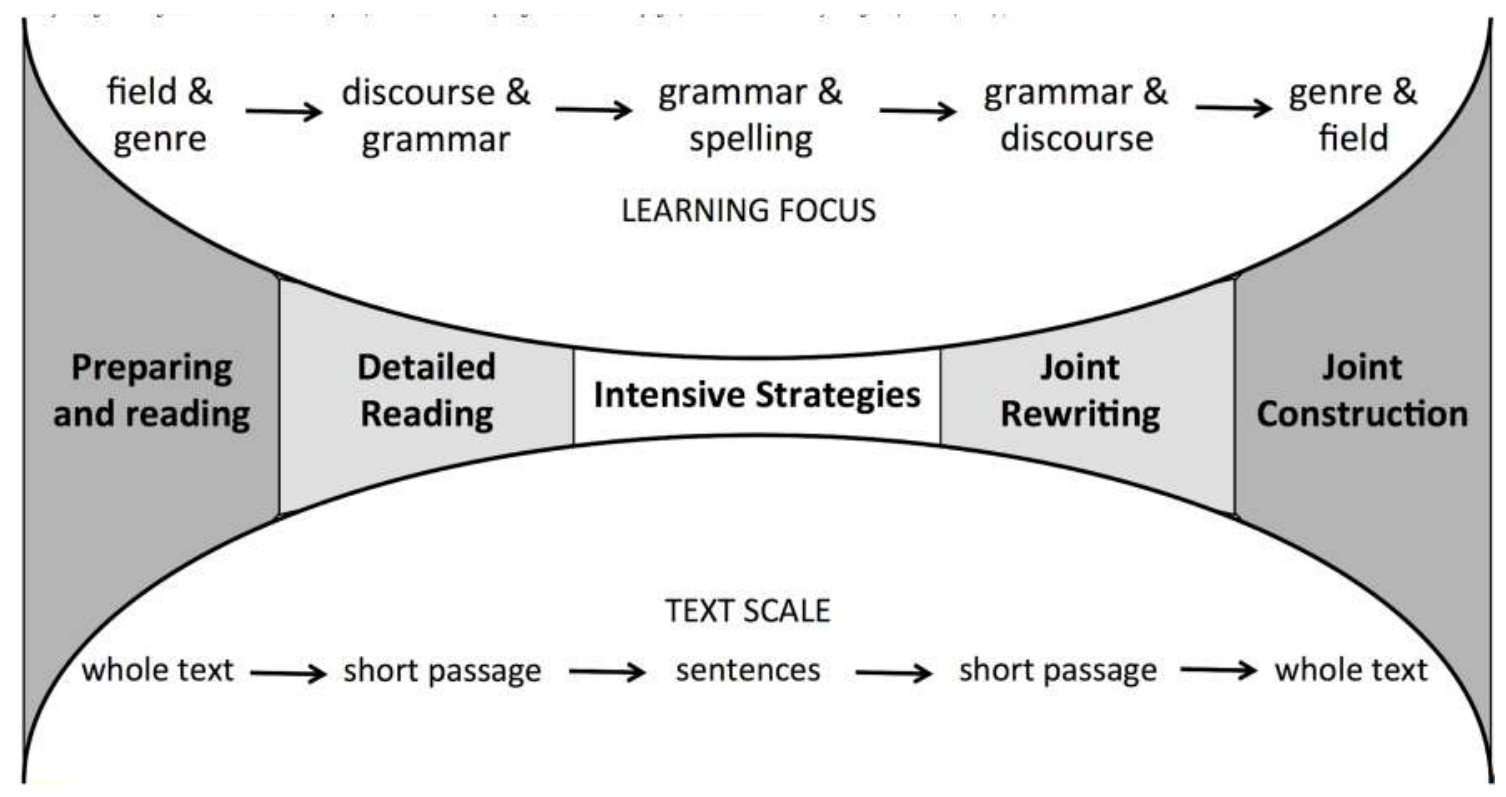

Figure 3 R2L's Integrated Learning Sequence

with a preview of its meanings and read aloud. Learners are then prepared to identify each wording by the teacher previewing its meaning. They highlight the wording and its meaning is then reviewed in more depth. Joint Construction of factual texts is prepared with Note Making from reading texts. Notes are jointly written on the class board, from the wordings highlighted in reading texts. The central task is then to write a new text from these notes, with the teacher's guidance. Joint Construction is ideally elaborated with Individual Construction, in which learners practice the same task with guidance and feedback

Table 1 Curriculum Genres in the R2L Bilingual Program

\begin{tabular}{llll}
\hline & \multicolumn{1}{c}{ Prepare } & \multicolumn{1}{c}{ Task } & Elaborate \\
\hline $\begin{array}{l}\text { Preparing for } \\
\text { Reading }\end{array}$ & $\begin{array}{l}\text { Overview of } \\
\text { text's field }\end{array}$ & $\begin{array}{l}\text { Read text } \\
\text { (aloud) }\end{array}$ & $\begin{array}{l}\text { Review key } \\
\text { points }\end{array}$ \\
Retailed & Preview sentence & $\begin{array}{l}\text { Read } \\
\text { sentence }\end{array}$ & \\
& Preview & Identify & Review \\
& meanings & wordings & meanings \\
& Noint & Text & Individual \\
Construction & Note making & negotiation & construction \\
\hline
\end{tabular}

from the teacher. The stages of these three curriculum genres are summarized in Table 1.

\section{The R2L Bilingual Program}

The R2L bilingual program ${ }^{2}$ adapted and extended this lesson sequence in three ways. Firstly, it deployed three iterations of the lesson sequence with increasing use of L2 in speaking, reading and writing, towards the final independent reading and writing task in L2. Secondly, it used the Note Making activity as the key point of reinstantiation between written wordings in $\mathrm{L} 1$ and L2. Third, it carefully designed learning cycles to use $\mathrm{L} 1$ judiciously to prepare and focus $\mathrm{L} 2$ reading and writing tasks.

In the three iterations of the R2L bilingual program, the first two reading texts were Indonesian texts about native Indonesian birds, while the third reading text was an English text about a native Australian bird. In each iteration, a report was jointly constructed in English using information from the reading texts. These joint constructions

2 Permission and consent to use all forms of data in this research have been obtained from the teacher, the students and the students' parents. 
were followed by individual constructions, in which students used the notes to reconstruct the text as homework, with teacher feedback. The final task was for learners to independently research and write a report in English on another bird species. This iterative sequence supported learners to build their repertoires of English lexicogrammar in manageable steps, while keeping the levels of genre, register and discourse relatively constant. As the discussion was also iterative, learners were able to build up their repertoires of both spoken and written English.

In the first two iterations, Note Making played a pivotal role in re-instantiation from L2 to L1. The Note Making activity involved three steps. In the first step, the teacher prepared an outline of the text organization, by scribing its stages and phases on the class board. The second step was to scribe notes under these sub-headings, from the wordings that learners had highlighted during Detailed Reading. Students took turns to scribe notes on the board, as other students took turns to dictate the highlighted wordings in their text copies. The third step was to re-instantiate each of the Indonesian wordings for notes and headings, into English wordings. This step was scribed by students in turn, guided by the teacher, with class discussion. These notes were then used to jointly construct a new text in English.

\section{Note Making Activities}

As outlined above, the R2L bilingual program adapts and extends the functions of Note Making in R2L for bilingual pedagogy. In the original R2L pedagogy, Note Making functions to mediate the re-instantiation of information from reading texts to writing new texts, through discussion and scribing activities. In the R2L bilingual program, it additionally functions to re-instantiate this information from L1 lexis to L2 lexis. In this activity, intermodality and multilingual reinstantiation are interwoven.

Multilingual re-instantiation is a significant departure from traditional approaches to building "vocabulary" in many EFL teaching methods (e.g. Webb \& Nation, 2017; Nation \& Meara, 2010). Rather than presenting lexical items in isolation, as in a dictionary or thesaurus, the items are first encountered in a meaningful text, embedded in the lexical relations that construct the field of a text. Higher level components of the language task, at the levels of genre, field, and discourse semantics are addressed first in L1, and this provides a supportive framework for the next step, of learning the L2 lexis that realizes the same field and lexical relations.

The bilingual Note Making activity consists of three phases: Build genre and register structuring $\wedge$ Scribe L1 wordings $\wedge$ Re-Instantiate L2 wordings $s^{3}$. In the building structure phase, the teacher prepares an outline of the text organization by scribing the stages of the genre and phases within each stage on the class board in L1. This text organization will be used as a guideline to scribe the notes, and then as a plan for jointly constructing a report in L2. The headings are scribed using initial capitals for generic stages, and lower case for register phases, to keep these levels distinct. The Note Making activity is illustrated in Figure 4.

In the lesson shown in Figure 4, the headings were scribed in red ink to make these metalinguistic terms distinct from the notes that were to be scribed beneath them. As the teacher wrote and explained these terms, the students transcribed them into their own notebooks, and were guided to rehearse their pronunciation with choral repetition. A line was then drawn to create two columns. In the right column, the teacher re-instantiated the Indonesian headings as English words. Again students rehearsed pronunciation with choral repetition, as they transcribed them into their books. To this point, the terms scribed on the board and in students' copies were as follows:

3 In systemic functional linguistics, the symbol $(\wedge)$ is a convention to indicate order and initial capital to indicate the name of structural function (see Halliday \& Matthiessen, 2014, p. ix). In this case, these indicate the order of structure phases in Note Making activity. 


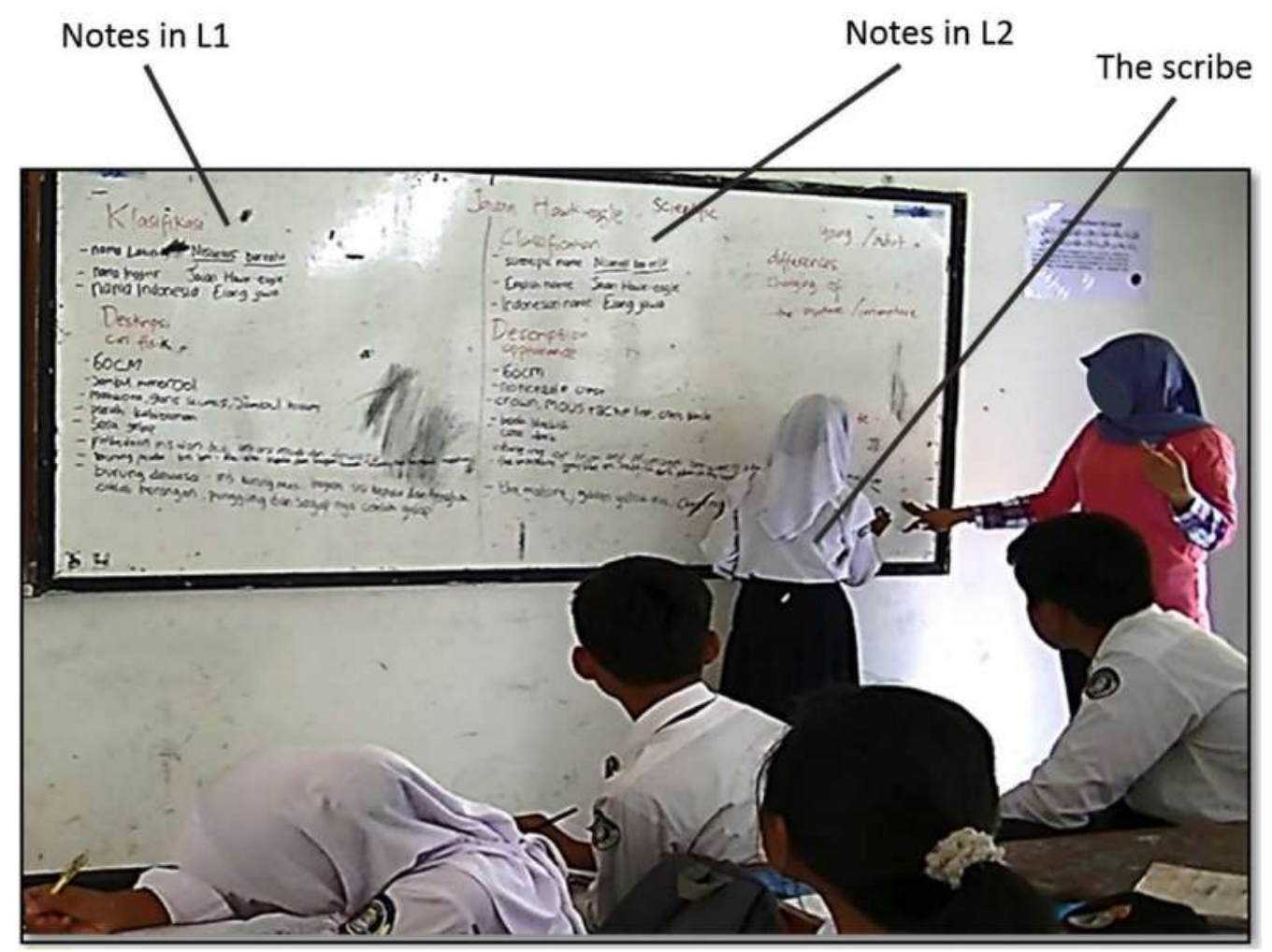

Figure 4 Note Making Activity

$\begin{array}{ll}\text { Klasifikasi } & \text { Classification } \\ \text { Deskripsi } & \text { Description } \\ \text { ciri fisik } & \text { appearance } \\ \text { habitat } & \text { habitat }\end{array}$

While scribing the L1 terms, the teacher explained the stages of descriptive reports and what should be written in each stage, recalling metalanguage first introduced in Preparing for Reading. Exchange 1 exemplifies the teacher's explanation. In the transcript, the teacher's Indonesian wording is presented and then glossed in English below each line. English wordings are presented in italics.

\section{Exchange 1: The Teacher Builds Genre Structure in the Beginning of Note Making Activity}

In $\mathrm{R} 2 \mathrm{~L}$ pedagogy, teacher monologues like this are typically kept very brief, before handing control over to learners for their own tasks. In this case, terms such classification and Latin name were already familiar from Detailed Reading of the source texts, so the explanation re-iterated familiar shared knowledge. As it elaborated existing knowledge, this allowed learners to focus on learning the metalinguistic terms.

In the next phase, Scribing L1 wordings, more control was handed to students as scribes and reciters, dictating and scribing meanings they had already identified, discussed and highlighted in Detailed

Exchange 1: The Teacher Builds Genre Structure in the Beginning of Note Making Activity

T Pertama, ketika kalian menulis deskriptif, ada yang disebut Identification atau Classification.

First, when you write a descriptive report, there is this called Identification or Classification.

[scribing Klasifikasi on board]

Bahasa Indonesia tetap ya Klasifikasi.

In Indonesian it is still, yes, Klasifikasi.

Klasifikasi itu isinya nama-nama, ada nama Indonesia, nama Latin, nama bahasa Inggris.

Classification consists of the names, which are Indonesian name, Latin name, English name. 
Reading. In this activity, the teacher plays a managerial role, appointing students to be scribe or reciter, and elaborating on meanings or writing tasks. In this respect, Note Making is a powerful activity for engaging all learners and building their control of reading and writing tasks. In appointing the scribe and reciter, the teacher may select a struggling learner, or one who is not paying attention. Distributing these roles ensures that all students are actively involved in the activity. While students take turns to scribe and recite, the other students transcribe what is written on the board into their notebooks, so that all students are engaged in the activity.

Exchange 2 illustrates the step of appointing a scribe. Using L1, the teacher identifies a student by name (here anonymized as S1) and directs her to come to the board. In this transcript each move is labelled with its role in the exchange, which shows us how the exchange is structured. The central role in a knowledge exchange is the primary knower, or K1. In an action exchange it is the primary actor, or A1. A seeker of information is a secondary knower (K2), and a demand for action is a secondary actor role (A2). In the first move here, the teacher asks for information as $\mathrm{K} 2$, and the student provides the information non-verbally, as $\mathrm{K} 1$. The teacher then demands an action as A2, and the student performs the action as A1.

\section{Exchange 2: The Teacher Appoints a Scribe}

Scribing notes begins in Exchange 3. The first cycle negotiates the first wordings to be scribed. The teacher first prepares the task, with the kind of information to be recited and scribed, and then

Exchange 2: The Teacher Appoints a Scribe

\begin{tabular}{lll}
\hline T & $\begin{array}{l}\text { Mana SI? } \\
\text { Where is SI? }\end{array}$ & K2 \\
S1 & {$[$ raising hand] } & $\mathrm{Kl}$ \\
\hline $\mathrm{T}$ & $\begin{array}{l}\text { Sini SI. } \\
\text { Come here SI. }\end{array}$ & $\mathrm{A} 2$ \\
S1 & [coming up \& holding a marker] & $\mathrm{Al}$ \\
\hline
\end{tabular}

asks the chosen reciter (S2) to identify the first name that has been highlighted. S2 reads this word out, the teacher affirms and shows the scribe (S1) where to write it on the board. Each move in this exchange is analyzed in three columns. The first labels the exchange roles, the second labels the phases in each learning cycle, and the third labels the sourcing of meanings, discussed below.

\section{Exchange 3a: Exchange and Activity in Scribing L1 Notes}

In this exchange the teacher starts as primary knower (K1), but then asks a question she already knows the answer to. The function here is for the learner to display knowledge which the teacher can evaluate. Even though the learner provides information, the teacher has final authority to evaluate it, so remains $\mathrm{K} 1$, while the learner is $\mathrm{K} 2$. The teacher's initial question delays her K1 evaluation, and is labelled $\mathrm{dK} 1$, for delayed primary knower. This is the exchange structure of the so-called "IRF" pattern of classroom discourse. It functions to create an active

Exchange 3a: Exchange and Activity in Scribing L1 Notes

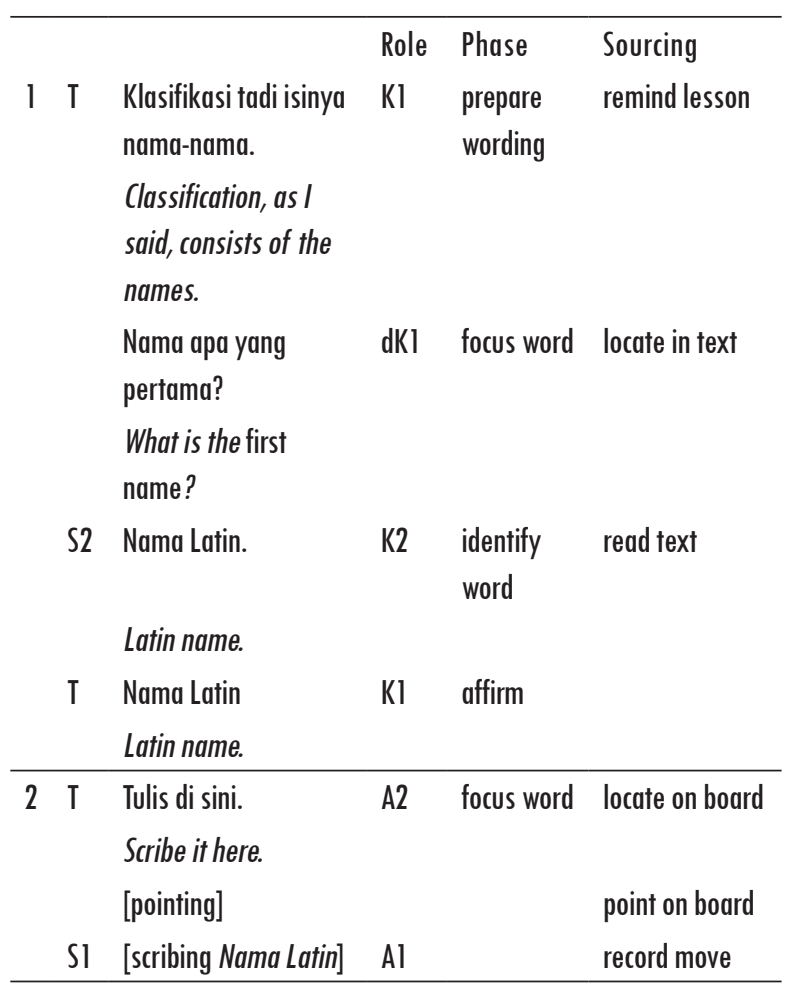


learning task, a vocal response, that can be evaluated for the benefit of both teacher and learners.

As shown in the phase column, the learning task here is to identify a word in the reading text. In the first cycle, this task is prepared with relevant information in the initial K1 move, then focused with the $\mathrm{dK} 1$ question, and finally affirmed. In the second cycle, the teacher directs the scribe. As shown in the sourcing column, the task is prepared by reminding learners of the prior lesson activity, and the focus precisely locates the word in the text as the first name, which the learner easily identifies by reading the highlighted text. In the second cycle, the teacher focuses the scribing task by locating and pointing where to write, and the scribe accurately records the recited word. Hence, both the structuring of learning cycles, and the sourcing of meanings, are critical considerations for analyzing and designing effective pedagogy.

This pattern is then repeated in cycles 3, 4 and 5, but now the scribe does not wait for the teacher, but simply writes what the reciter has said. The teacher's focus questions now function to hand control to the reciter and scribe, who are confident to continue the activity. Their confidence flows from continual success and affirmation that R2L learning cycles are designed to ensure for all learners. As in cycle 1, the identifying tasks are again focused by precisely locating the next wording with second, and after the Latin name. At this stage of the lesson, learning tasks are also made easier by conducting the exchange wholly in L1, with the exception of the Latin name Nisaetus bartelsi, which has already been rehearsed in Detailed Reading.

\section{Exchange 3b: Continuing Exchange and Activity of Scribing L1 Notes}

The notes scribed to this point are as follows:

Klasifikasi

- nama Latin: Nisaetus bartelsi

- nama Inggris: Javan Hawk-eagle
In the third phase of Note Making, Re-instantiating as L2 wordings, the goal is to choose L2 lexical items to re-instantiate the L1 items in the notes. Two scenarios may occur depending on the students' familiarity with the L2 words. If the L2 wording is relatively new and not introduced in Detailed Reading, the teacher may explicitly state the word and may write it on the board for the scribe to copy into the notes. This occurs in the first cycle of Exchange 4. The teacher prepares with the known words Latin name and a new alternative, scientific name, and writes the new L2 word scientific on the board, which the scribe can copy. In contrast, in cycles 2 and 4 the teacher simply asks for English wordings and the students propose these L2 wordings from their own knowledge.

Exchange 3b: Continuing Exchange and Activity of Scribing L1 Notes

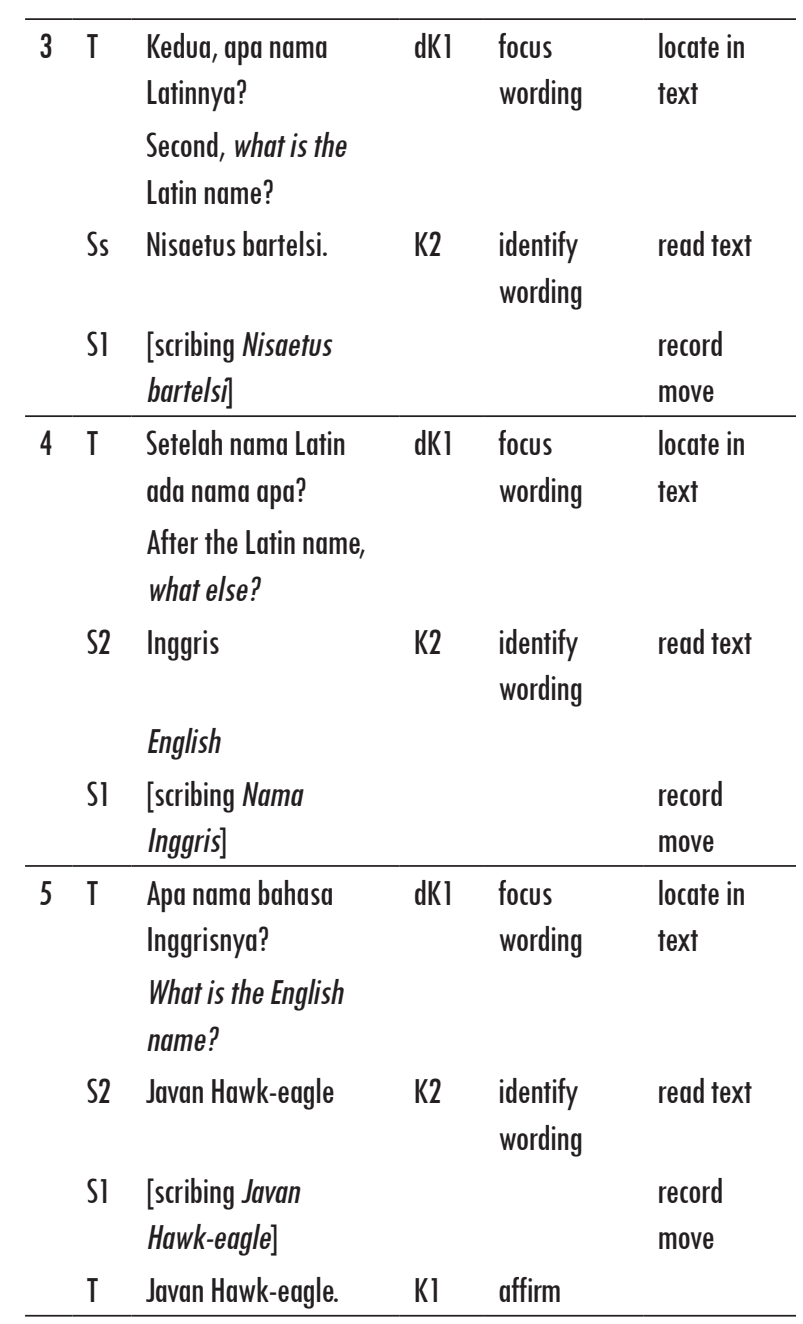




\section{Exchange 4: The Teacher Guides the Students} in Reinstantiating L1 Notes to L2 Wordings

The re-instantiated notes to this point are shown in Table 2.

Table 2 Re-instantiated Notes

\begin{tabular}{ll}
\hline \multicolumn{1}{c}{ Notes in L1 } & \multicolumn{1}{c}{ Re-instantiatied in L2 } \\
\hline Klasifikasi & Classification \\
- nama Latin: Nisaetus bartelsi & - scientific name: Nisaetus \\
- nama Inggris: Javan Hawk-eagle & bartelsi \\
- nama Indonesia: Elang jawa & - English name: Javan \\
& Hawk-eagle \\
& - Indonesian name: Elang \\
& jawa \\
\hline
\end{tabular}

In Exchanges 5a and 5b, notes from the appearance phase of the Description are re-instantiated in L2. These L2 wordings have already been discussed during Detailed Reading, so the source is recalling this prior lesson. In cycles 1 and 2, the teacher focuses by giving L1 wordings, and students propose $\mathrm{L} 2$ words. In cycle 1 , the focus is the L1 nominal group, jambul menonjol, but students only propose the L2 noun crest. In cycle 2, the teacher re-focuses the associated quality menonjol, students propose the L2 adjective noticeable, and the teacher elaborates with the whole L2 nominal group.

\section{Exchange 5a: A Typical Exchange of Re-Instantiating Familiar L2 Lexis}

In addition to lexicogrammar, cycles 3 and 4 illustrate negotiation of graphology, of spelling and lettering. In cycle 3, the teacher nominates a student to recite the $\mathrm{L} 2$ spelling. However, the scribe uses an incorrect letter case, which is negotiated in cycle 4 . Here the source of spelling and lettering is learner's knowledge.

Exchange 4: The Teacher Guides the Students in Reinstantiating L1 Notes to L2 Wordings

\begin{tabular}{|c|c|c|c|c|c|}
\hline \multirow[t]{8}{*}{1} & $\mathrm{~T}$ & Ada yang menyebut Latin name. & Kl & prepare L2 wording & read text \\
\hline & & Some call it the Latin name. & & & \\
\hline & & Ada yang menyebut scientific name. & & & teacher knowledge \\
\hline & & Some call it scientific name. & & & \\
\hline & & [scribing scientific on the board] & & & record move \\
\hline & & Kita pakai scientific name. & $\mathrm{A} 2$ & focus L2 wording & \\
\hline & & Let's use "scientific name". & & & \\
\hline & SI & [scribing scientific name] & Al & & copy from board \\
\hline \multirow[t]{5}{*}{2} & $\mathrm{~T}$ & Nama Inggris disebut apa bahasa Inggrisnya? & $\mathrm{dKl}$ & focus L2 wording & \\
\hline & & What is nama Inggris in English? & & & \\
\hline & Ss & English name & K2 & propose L2 wording & learner knowledge \\
\hline & $\mathrm{T}$ & English name & $\mathrm{Kl}$ & affirm & \\
\hline & SI & [scribing English name: Javan Hawk-eagle] & & & record move \\
\hline \multirow[t]{4}{*}{3} & $\mathrm{~T}$ & Nah, terakhir nama Indonesia? & $\mathrm{dKl}$ & focus LI wording & \\
\hline & & Now, the last one is Nama Indonesia & & & \\
\hline & Ss & Elang jawa & K2 & identify LI wording & learner knowledge \\
\hline & $\mathrm{T}$ & Elang jawa & Kl & affirm & \\
\hline \multirow[t]{5}{*}{4} & $\mathrm{~T}$ & Nama Indonesia? & $\mathrm{dK} 1$ & focus L2 wording & \\
\hline & & Nama Indonesia in English? & & & \\
\hline & S3 & Indonesian name. & K2 & propose L2 wording & learner knowledge \\
\hline & $\mathrm{T}$ & Indonesian name & Kl & affirm & \\
\hline & SI & [scribing Indonesian name: Elang jawa] & & & record move \\
\hline
\end{tabular}


Exchange 5a: A Typical Exchange of Re-Instantiating Familiar L2 Lexis

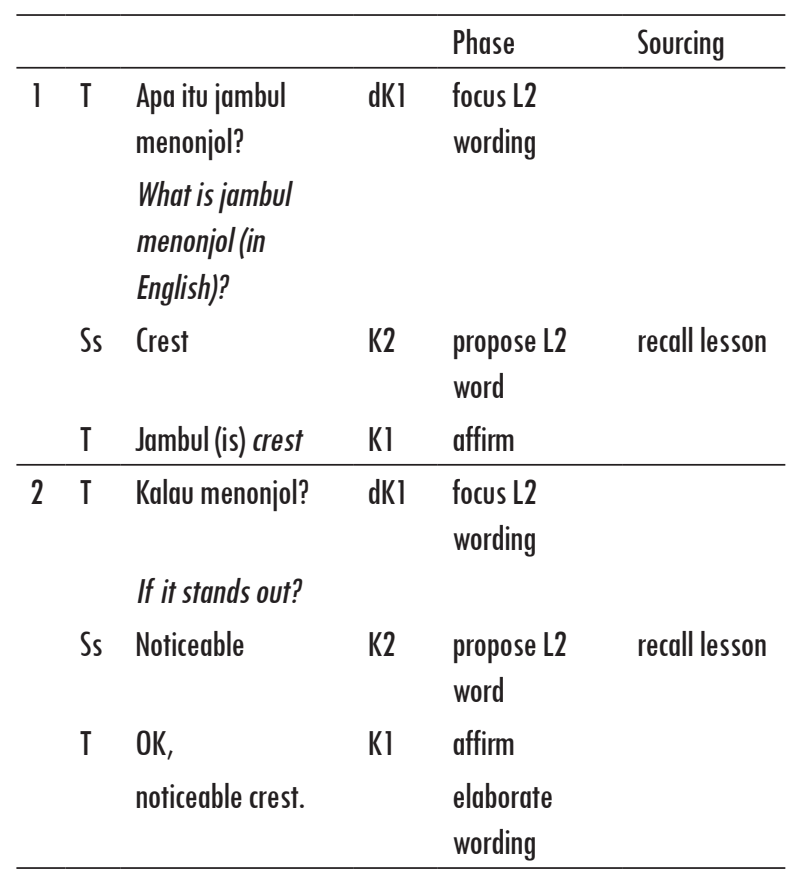

\section{Exchange 5b: Continuing Exchange of Reinstantiating Familiar L2 Lexis to Scribing Activity}

The reinstantiated notes are illustrated in Table 3 .

Exchanges 3, 4, and 5 ( $\mathrm{a}$ and $\mathrm{b}$ ) illustrate the tripartite intermodal work of reciting and scribing in Note Making. Sourcing includes the reading text,

Table 3 Re-Instantiated Notes

\begin{tabular}{|c|c|}
\hline Notes in L1 & Re-instantiatied in L2 \\
\hline Klasifikasi & Classification \\
\hline -nama Latin: Nisaetus bartelsi & -scientific name: Nisaetus \\
\hline -nama Inggris: Javan & bartelsi \\
\hline Hawk-eagle & -English name: Javan Hawk-eagle \\
\hline -nama Indonesia: Elang jawa & -Indonesian name: Elang jawa \\
\hline Deskripsi & Description \\
\hline ciri fisik & appearance \\
\hline$-60 \mathrm{~cm}$ & $-60 \mathrm{~cm}$ \\
\hline -jambul menonjol & -noticeable crest \\
\hline -mahkota, garis kumis, jambul & -crown, moustache line, crown \\
\hline hitam & black \\
\hline -paruh kehitaman & -beak blackish \\
\hline -sera gelap & -cere dark \\
\hline$\ldots$ & $\ldots$ \\
\hline
\end{tabular}

Exchange 5b: Continuing Exchange of Reinstantiating Familiar L2 Lexis to Scribing Activity

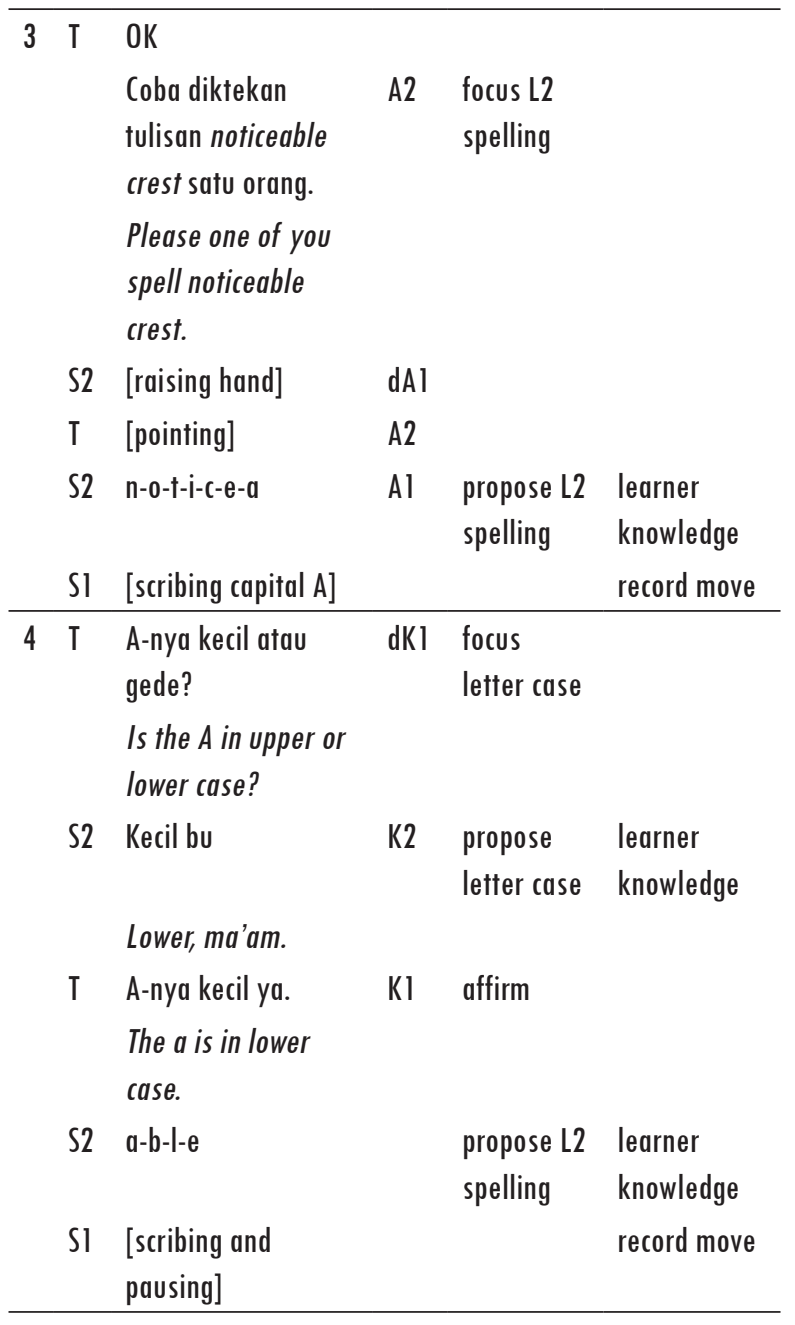

L1 notes scribed on the board and L2 re-instantiations, along with the knowledge of teacher and learners. The reciter must pay careful attention to the reading text and watch the scribe in order to provide assistance as needed, whereas the scribe must listen carefully to the reciter's dictation, and the teacher must attend to both and guide the exchange. This support lessens the burden of being in the front of the class, so that struggling learners can be selected for scribing. While they actively learn skills such as spelling and lettering, the whole class benefits from the lesson. Note Making is a cooperative activity that helps to build an ethic of mutual support through learning in an affirming safe environment. 


\section{Text Negotiation Activities}

The goal of Joint Construction in the R2L bilingual program is to construct a new text in the target genre, using the re-instantiated notes from Note Making. In the Text Negotiation stage, the teacher guides learners to use the L2 notes, to construct new L2 grammar and discourse patterns. As the genre, field and lexical items were addressed in Note Making, students can now focus on learning L2 grammar. As with Note Making, Text Negotiation is an intermodal activity, and the classroom is organized similarly to facilitate this. The board used for Joint Construction is positioned beside the board with the notes (Figure 5). This positioning allows the teacher to manage the intermodal activity, to refer and point to the note making board, making the source of meanings concrete and visible for the students. It also allows students to check and keep track of the text organization and the wordings in the notes, so they can explicitly negotiate the L 2 wordings into new sentences.

Text Negotiation in the R2L bilingual program weaves together multilingual re-instantiation with intermodality. It is a significant advance on mainstream EFL teaching approaches, in which writing practices in L2 are often encouraged without systematically considering the L1 role may play in the process (e.g. Tribble, 2001; Hyland, 2010). Joint Construction in the R2L bilingual program begins with shared knowledge of the genre and register, through reading and discussion in $\mathrm{L} 1$, and re-instantiation of the field in the L2 notes. Familiarity with these dimensions of the learning task allows learners to concentrate on grammar and discourse structures required for constructing a new L2 text. Again, L1 can be used judiciously to discuss features of grammar and discourse, which will ultimately be re-instantiated in L2 sentences. This is an intermodal and multilingual activity, from the L2 notes, through discussion in L1 and L2, to the new L2 text.

Iterated steps in Text Negotiation consist of Plan text phase $\wedge$ Construct L2 sentences. In the Plan step, the teacher previews the organization of the new text at the levels of genre and register, using the L2 metalinguistic terms built up in Note Making. This is illustrated in Exchange 6 , in which the teacher prepares by reminding of shared knowledge from the prior lesson,

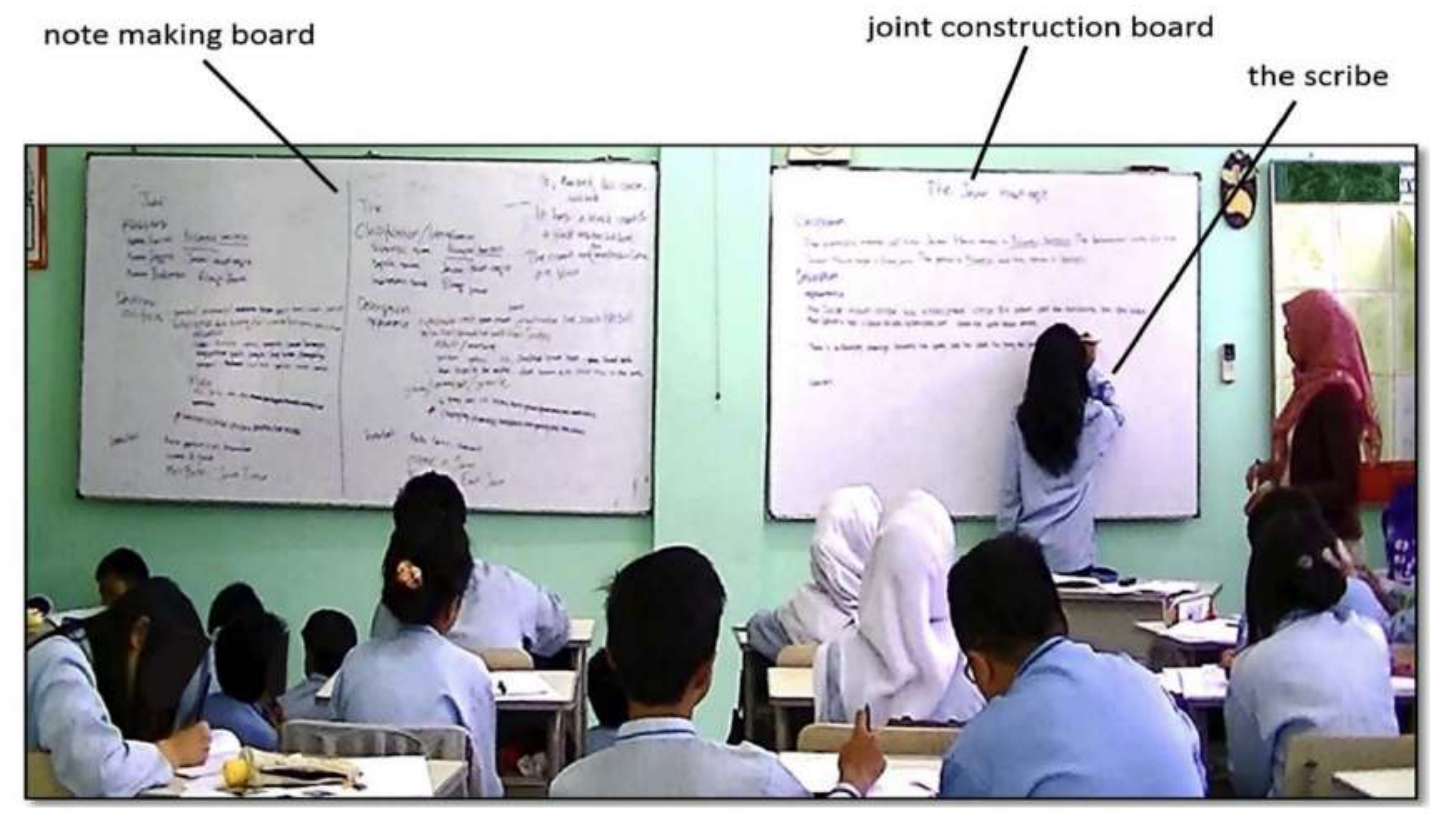

Figure 5 Joint Construction Lesson 
including the Classification stage and its components, and adds new information that it will be written as a paragraph in the new text. The scribe is then directed to start with the title.

\section{Exchange 6: The Teachers Sets out the Genre Stages for the Joint Text}

Negotiation in the sentence constructing phase is more complex than that in Note Making. Although the class has the lexical items and word groups in the notes to draw on, the teacher must guide learners to organize them in appropriate L2 grammar structures, without simply telling them what to write. In the first cycle of Exchange 7, the teacher makes the task easier by focusing with the sentence structure in L1, so that a student can propose the same sentence structure in L2.

Exchange 6: The Teachers Sets out the Genre Stages for the Joint Text

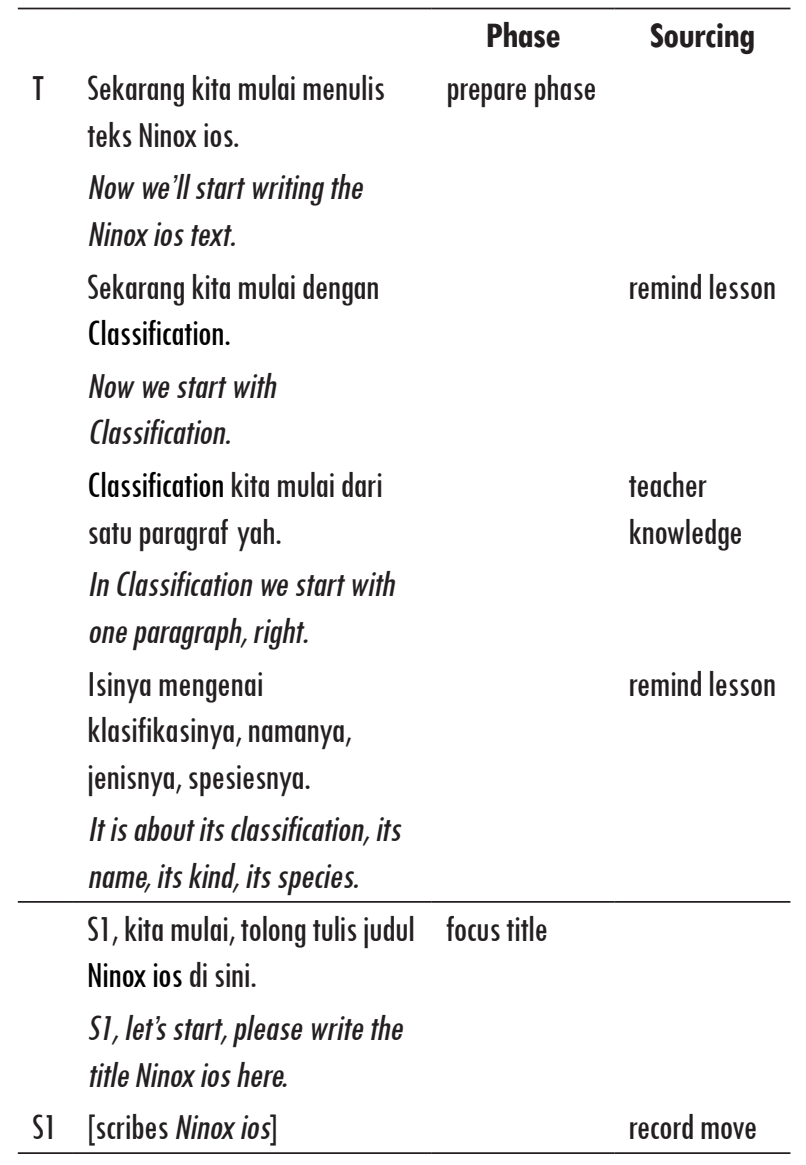

\section{Exchange 7a: Construct L2 Sentence Begins with a Student Proposing a Sentence}

While the teacher supplied the overall sentence structure in the L1 focus, the learner's task included re-instantiating the L1 nominal group nama ilmiahnya as an appropriate L2 nominal group the scientific name. This involved reversing the order of items and re-instantiating the possessive deixis as the English article the. The supportive focus question and prior discussion during Note Making facilitated this task.

Exchange 7a: Construct L2 Sentence Begins with a Student Proposing a Sentence

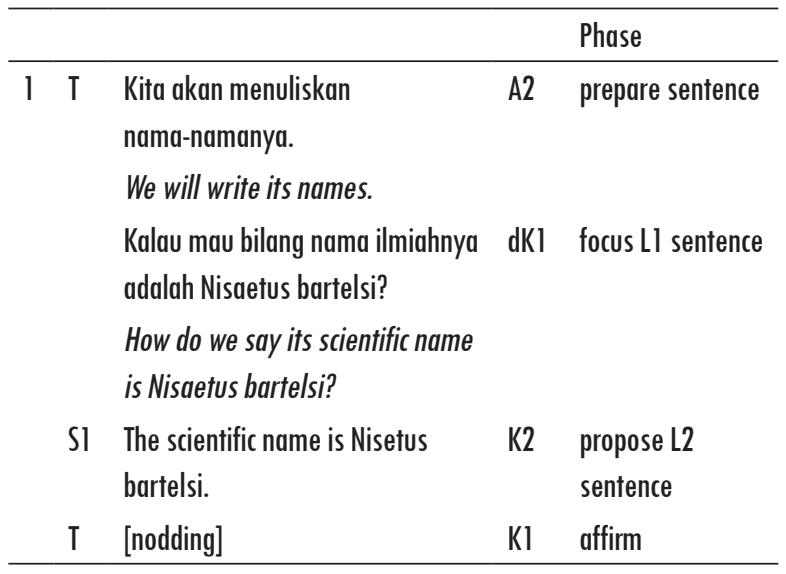

In addition, this sentence lacks a piece of information that needed adding to the nominal group. In the second cycle the teacher focuses the type of information needed in L1 and provides it in L2, the Javan Hawk Eagle. She then focuses the sentence and provides the whole nominal group that will be the Theme of the sentence, in L1. This is sufficient support for a student to propose the entire sentence in L2. The sentence is then completed in cycle 3 , by focusing on the punctuation.

\section{Exchange 7b: Construct L2 Sentence Continues by Students Revising and Scribing Sentences}

The thematic organization of a sentence is also the topic of Exchange 8. Here the teacher focuses in L1 by restating the sentence proposed by one student, 
Exchange 7b: Construct L2 Sentence Continues by Students Revising and Scribing Sentences

\begin{tabular}{|c|c|c|c|c|}
\hline \multirow[t]{17}{*}{2} & \multirow[t]{12}{*}{$\mathrm{T}$} & Tapi nama ilmiahnya siapa? & $\mathrm{dKl}$ & focus LI wording \\
\hline & & But whose scientific name? & & \\
\hline & & The Javan Hawk Eagle, kan? & Kl & prepare L2 \\
\hline & & & & wording \\
\hline & & The Javan Hawk Eagle, right? & & \\
\hline & & Jadi, menulisnya di sini & $\mathrm{dK} 1$ & focus sentence \\
\hline & & bagaimana? & & \\
\hline & & So, how to put it here? & & \\
\hline & & Nama ilmiah the Javan & $\mathrm{Kl}$ & prepare LI \\
\hline & & Hawk-eagle. & & Theme \\
\hline & & The scientific name of the & & \\
\hline & & Javan Hawk-eagle. & & \\
\hline & SI & The scientific name of the & K2 & propose L2 \\
\hline & & Javan Hawk eagle is Nisaetus & & sentence \\
\hline & & bartelsi. & & \\
\hline & $\mathrm{T}$ & [nodding] & $\mathrm{Kl}$ & affirm \\
\hline & S2 & [scribing sentence] & & \\
\hline \multirow[t]{7}{*}{3} & $\mathrm{~T}$ & After a sentence, you need to & A2 & focus \\
\hline & & put a period. & & punctuation \\
\hline & S2 & [scribing a period] & $\mathrm{Al}$ & \\
\hline & $\mathrm{T}$ & That's very good. & $\mathrm{A} 2 \mathrm{f}$ & affirm \\
\hline & & The scientific name of the & & \\
\hline & & Javan Hawk eagle is Nisaetus & & \\
\hline & & bartelsi. & & \\
\hline
\end{tabular}

implicitly asking for other proposals. Another student proposes reversing the order in L1, to start with the word Indonesian as Theme. The teacher focuses by asking how in L1, and the student proposes the L2 sentence, which the teacher affirms and scribes.

\section{Exchange 8: A Student Proposes L2 Sentence}

Such cases, when two different sentences have been proposed, provide additional opportunities for discussing language. The teacher may scribe both wordings on the board, close by the jointly constructed text. The two proposed wordings may then be compared to consider which is most appropriate for the text, with the teacher explaining their language features. When both wordings seem equally appropriate, the class may vote for one
Exchange 8: A Student Proposes L2 Sentence

\begin{tabular}{|c|c|c|c|}
\hline & & & Phase \\
\hline $\mathrm{T}$ & $\begin{array}{l}\text { Tadi SI punya usul lagi bilangnya "Punggok } \\
\text { Minahasa is the Indonesian name of Ninox } \\
\text { ios". } \\
\text { Sl suggested again, he said "Punggok } \\
\text { minahasa is the Indonesian name of Ninox } \\
\text { ios". }\end{array}$ & Kl & $\begin{array}{l}\text { focus LI } \\
\text { sentence }\end{array}$ \\
\hline S2 & $\begin{array}{l}\text { Better use the word Indonesian first, } \\
\text { ma'am. }\end{array}$ & K2 & $\begin{array}{l}\text { propose Ll } \\
\text { Theme }\end{array}$ \\
\hline $\mathrm{T}$ & $\begin{array}{l}\text { Atau gimana? } \\
\text { Or how is it? }\end{array}$ & $\mathrm{dK} 1$ & $\begin{array}{l}\text { focus } \\
\text { sentence }\end{array}$ \\
\hline S2 & $\begin{array}{l}\text { The Indonesian name of Cinnabar Hawk- } \\
\text { owl is Punggok minahasa. }\end{array}$ & K2 & $\begin{array}{l}\text { propose } \mathrm{L} 2 \\
\text { sentence }\end{array}$ \\
\hline $\mathrm{T}$ & $\begin{array}{l}\text { OK. } \\
\text { [scribing] }\end{array}$ & KI & affirm \\
\hline
\end{tabular}

or the other. In this case, the alternative sentence structures would provide an opportunity for discussing their functions at the level of discourse semantics. Here, starting with the Indonesian name, follows the pattern of types of names in this phase of the text. This could be pointed out on the board, with or without the technical metalanguage of Theme ${ }^{4}$.

Exchange 9 also illustrates the effective teacher practice of providing the Theme of a sentence for learners to complete it. In cycle 1, the scribe asks in L1 for the sentence, and the teacher focuses with the Theme in L2, while pointing at the relevant wording in the notes, which the scribe records. This is sufficient support for the reciter (S2) to rephrase the notes as the remainder of the sentence (its Rheme). However, this proposal has a grammatical problem. In cycle 2, the teacher asks for the English article the, while pointing at the board. This is sufficient for the reciter to rephrase

4 Theme, conventionally written with a capital letter, is "the element that serves as the point of departure of the message" (see Halliday \& Matthiessen, 2014, p. 89). 
the previous move as a correct nominal group in L2, which the scribe records. The sentence is then completed by negotiating punctuation.

\section{Exchange 9: A Volunteer Helps the Reciter by Restating the Wordings to the Scribe}

Another feature of Exchange 9 is that a third student $(\mathrm{S} 3)$ restates the reciter's proposals. In a big

Exchange 9: A Volunteer Helps the Reciter by Restating the Wordings to the Scribe

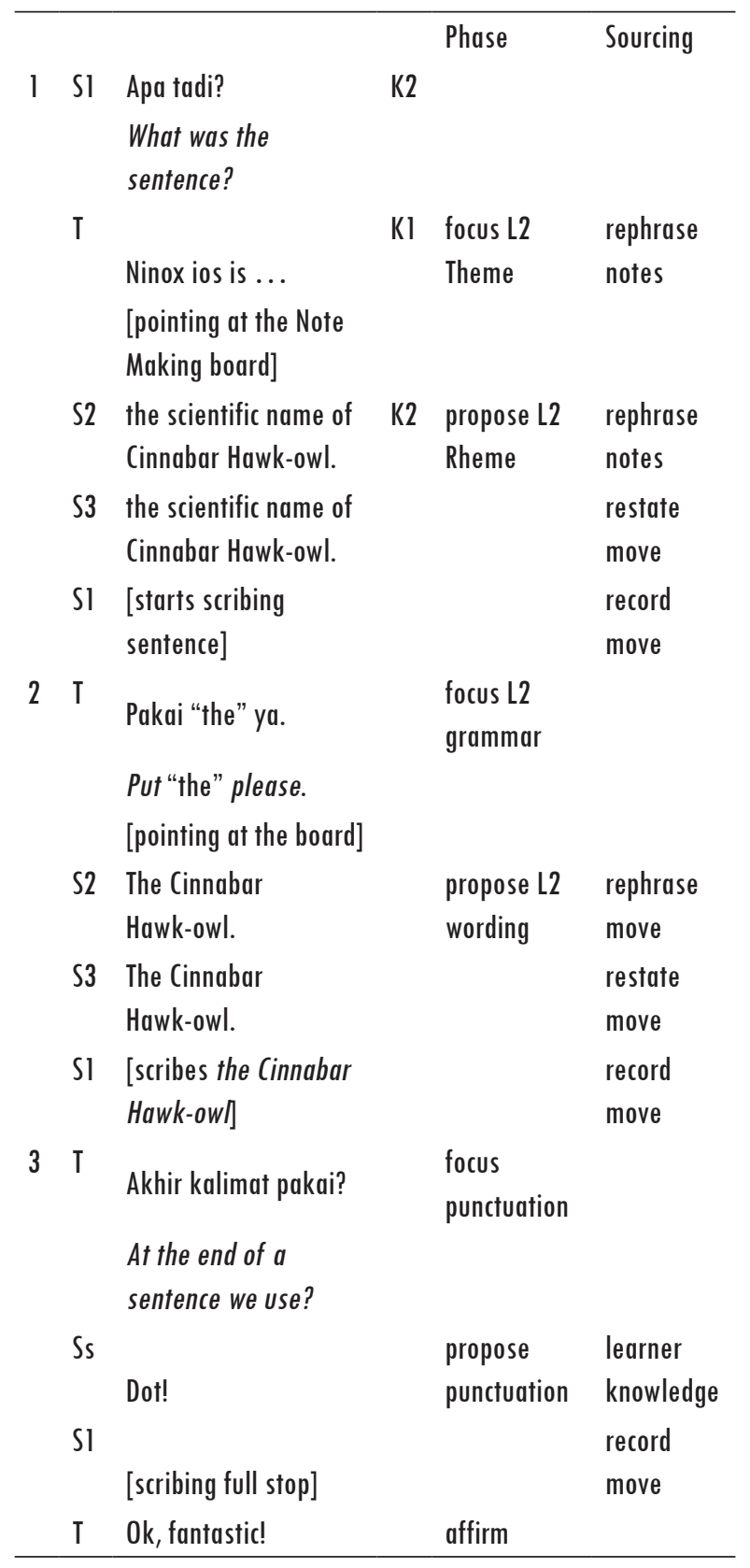

class of more than 30 students, the appointed reciter is sometimes sitting in the back, and may not be heard clearly by the scribe. Here a volunteer seated close to the front may convey the message from the reciter to the scribe (Figure 6). Such additional help during the intermodal exchange is indicative of the supportive learning environment built up through R2L's cooperative activities.

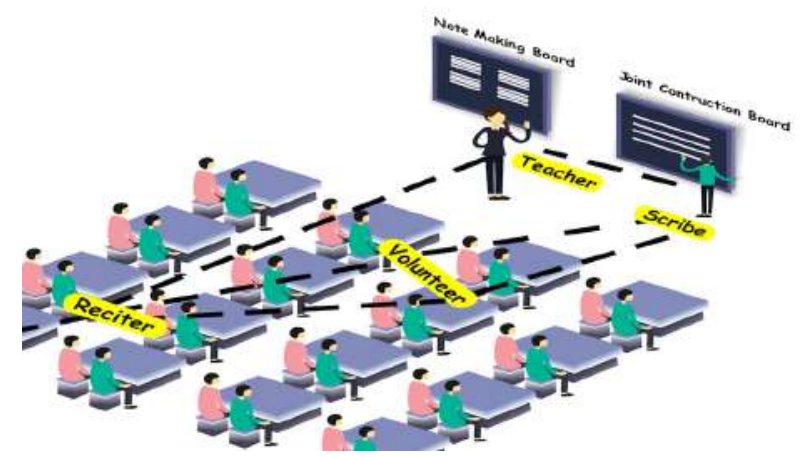

Figure 6 A Volunteer Mediating Reciter and Scribe

\section{Discussion: Approaches to Joint Construction in Genre Pedagogy}

Joint Construction in the R2L bilingual program is significantly different from earlier genre-based approaches to writing that are familiar to many (Emilia, 2011; Humphrey \& Macnaught, 2011; Hunt, 1991; Purser et al., 2020). The design of the GBA teaching/learning cycle (TLC), centered on Joint Construction, was a breakthrough in writing instruction in the 1980s, as it combined the scaffolding principle of "guidance through interaction in the context of shared experience" with explicit knowledge about the structuring of target genres (Rose \& Martin, 2012). It was a major advance in traditional formulaic composition approaches, and in the opposing progressivist method of writing from personal experience.

The R2L bilingual approach refines and extends GBA in three dimensions. The first is the staging of the curriculum genre. The basic model of the GBA TLC includes Deconstruction of a genre model, Joint Construction, and Independent Construction, with "building the field" distributed 
non-specifically through these stages (Rothery \& Stenglin, 1994; Rose \& Martin, 2012). This staging has since been analyzed in more detail by Christie (2005), Humphrey \& Macnaught (2011), Purser et al. (2020), among others, to include stages such as Genre Review, Bridging, Task Negotiation, and Review. In the genre/register model applied here, most of these activities are phases within the central Text Negotiation stage of the joint construction curriculum genre. Stages are obligatory units of genre structuring; phases are more variable units of register that realize genre stages (Martin \& Rose, 2007, 2008).

In the R2L bilingual program, field building occurs specifically as learning through reading, in the activities of Preparing for Reading and Detailed Reading. Deconstruction of the genre is a phase in the Note Making activity, in which genre and register structuring is built up with headings on the notes. This approach serves to embed the abstract categories of text structuring, with the details of the field that learners are already familiar with, so that all learners acquire the principle. Note Making is a considerably more supportive preparation for the task of constructing the new text. This writing stage is named Text Negotiation in GBA, following Christie (2005), but in the R2L bilingual program this negotiation is highly designed.

These pedagogic relations are another dimension of difference. In the R2L bilingual approach, meanings and wordings are negotiated through carefully designed learning cycles, which are prepared and focused to ensure that all learners are continually successful and affirmed. In the Note Making stage, this is accomplished by focusing on the wordings in reading texts that learners are already familiar with and locating them precisely. In the Joint Construction stage, it is achieved by focusing on the notes that are already familiar, and building sentences in manageable steps, using techniques such as providing the Theme to complete the sentence or providing a simple nominal group and expanding it (Exchange 7).
Furthermore, this negotiation is tripartite, as it is not just between the teacher and class, but between the teacher, and a nominated reciter and a scribe, along with the rest of the class. This is a major departure from common teaching practice, in which a few students in each class consistently respond in teacher/class interactions (Nuthall, 2005, Rose \& Martin, 2012), and most writing on the board is done by the teacher. In contrast, the R2L bilingual program ensures that every student is actively involved in the class conversation, by directing focus questions to each student by name, and continually affirming them. It also ensures that control is handed over to all learners by nominating them for reciting and scribing roles, which they manage cooperatively.

The third dimension of difference is the design of multilingual re-instantiation through intermodality. Through each activity of Preparing for Reading, Detailed Reading and Joint Construction, learning language and learning about language are embedded in the curriculum goals of learning through language (Halliday, 1993). Moreover, this learning is deliberately bilingual and multimodal. In the first two iterations of the R2L bilingual lesson sequence, learning genre and register begin in L1 with Preparing for Reading then deepen in Detailed Reading. Learning the discourse and grammar patterns of L2 begin with Note Making, and moving deeper in Joint Construction, through re-instantiation of L1 into L2 lexis and grammar. The critical consideration here is the sourcing of meanings and wordings. In contrast to common GBA practice, sourcing in R2L bilingual activities is carefully targeted in reading texts and written notes that are visible to all along with teacher knowledge and learner knowledge that is shared by all.

The benefits of this re-design of Joint Construction in the R2L bilingual program are its outstanding outcomes, both for learners' curriculum knowledge and L2 language skills. The study outlined above compared participants' independent writing skills before and after the intervention (KartikaNingsih, 2016; in press), along with their spoken 
language development (Kartika-Ningsih, 2019). Figures 7 and 8 illustrate the writing growth achieved by even the weakest students over the six-week intervention.

The cat
I have a pet it is a cat. The colour of my
cat is white. Every morning. I always feed
The cat wit fish. Habits that my cat always
Want to be loved. I am there fore verry happy
cats.

Figure 7 Pre-Intervention Writing Text (The Cat)

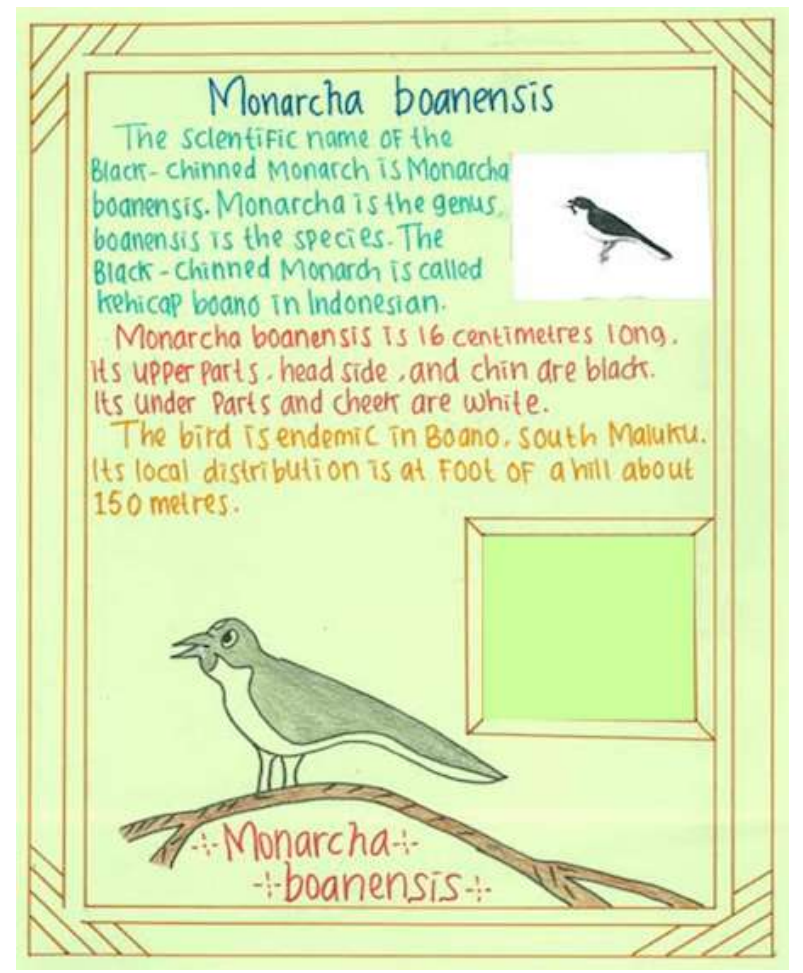

Figure 8 Post-Intervention Writing Text (Monarcha boanensis)

Both these texts were written independently by the same student. For the pre-intervention task, students were asked to write a description about their favorite animals, including features such as color and habits. For the post-intervention task, they were required to independently research a bird species and write a descriptive report about it.

Text 1 illustrates writing results typically found across classrooms in Grade 8 ( $14-15$ years old), in Indonesian junior high schools after several years of EFL teaching (Emilia, 2011). Texts are often very short like this, made up of a few short sentences that include only lexis and grammar that the student is confident to use, without being over-corrected.

In Text 2 the same student is now able to confidently use appropriate patterns of field, discourse, grammar and lexis that would be highly valued in schools with English as a first language. The student has acquired this knowledge, not only through guided practice in Joint Construction, but through iterations of Preparing for Reading, Detailed Reading and Note Making, negotiated and re-instantiated between L1 Indonesian and L2 English.

\section{Conclusion}

We began this paper with the model of meaning-making we used to design the R2L bilingual program: of genres realized as registers realized as language; of texts instantiating meanings at each of these levels; and of cultures as reservoirs of meanings that are individuated in the repertoires of each person. By taking these three dimensions into account, the R2L bilingual program addresses a number of problems with current EFL practice. Firstly, our understanding of realization allows us to embed language in curriculum content learning in one and the same activity, instead of teaching language as a separate curriculum topic. Second, our view of instantiation enables us to re-instantiate meanings from L1 texts to L2 texts, mediated by spoken L1 and L2, to rapidly accelerate language learning, instead of gradually building L2 vocabulary and grammar like bricks-\&-mortar. Thirdly, our interest in individuation drives us to design pedagogic activities that ensure that every learner is continually successful and affirmed in each learning task, reaching towards success for all with curriculum goals.

The vehicle for these ambitions is the design of curriculum genres in the R2L bilingual program. We interpret their curriculum registers in terms 
of the knowledge genres that students will learn to read and write in L1 and L2. To this end, we have designed their pedagogic registers as a sequence of activities that lead from reading in L1 to writing in L2. These activities are designed as intermodal and multilingual, continually re-instantiating meanings from $\mathrm{L} 1$ reading texts, through oral learning cycles, to L1 and then L2 notes, and again through carefully designed learning cycles, to L2 grammar and discourse patterns in writing. These intermodal, multilingual activities are negotiated through pedagogic relations, that are not simply between teacher and class, but through tripartite exchanges between teacher, reciters and scribes, that ensure that every student is active and supported to succeed.

\section{References}

Becerra, T., Herazo, J., García, P., Sagre, A., \& Díaz, L. (2020). Using Reading to Learn for EFL students' reading of explanations. ELT Journal, 74(3), 237-

Christie, F. (2005). Classroom discourse analysis: A functional perspective. Bloomsbury Publishing.

Coffin, C., Acevedo, C., \& Lövstedt, A. C. (2013). Teacher learning for European literacy education (TeL4ELE) Final report. Public part.

Dell, S. (2011, April 3). Reading revolution [blog post]. Mail \& Guardian Online. http://mg.co.za/ article/2011-04-03-reading-revolution

Emilia, E. (2011). Pendekatan Genre-based dalam Pengajaran Bahasa Inggris: Petunjuk untuk Guru. Bandung, Rizqi Press.

Halliday, M. A. K. (1993). Towards a language-based theory of learning. Linguistics and Education, 5, 93-116. https://doi.org/10.1016/0898-5898(93)90026-7

Halliday, M. A. K. \& Greaves, W. S. (2008). Intonation in the grammar of English. Equinox Pub.

Halliday, M. A. K \& Hasan, R. (1976). Cohesion in English. Longmans.

Halliday, M. A. K. \& Matthiessen, C. M. I. M. (2014). An introduction to functional grammar. Routledge.

Hyland, K. (2010). Teaching and researching writing: Applied linguistics in action. Routledge.
Humphrey, S. \& Macnaught, L. (2011). Revisiting joint construction in the tertiary context. The Australian Journal of Language and Literacy, 34(1), 98-115. https://search.informit.com.au/documentSummar $\mathrm{y} ; \mathrm{dn}=729761300475762 ;$ res=IELHSS

Hunt, I. (1991). Negotiation in joint construction: Teaching literacy in early childhood. (Unpublished Honours Thesis), University of Sydney, Australia.

Kartika-Ningsih, H. (2016). Multilingual re-instantiation: Genre pedagogy in Indonesian classrooms. (Unpublished Ph. D. thesis), University of Sydney, Australia.

Kartika-Ningsih, H. (2019). Implementing the Reading to Learn Bilingual Program in Indonesia. In K. Rajandran \& S. Abdul-Manaf (Eds.), Discourses of Southeast Asia (pp. 145-163). Springer.

Kartika-Ningsih, H. (in press). The application of R2L methodology in EFL classrooms: A bilingual approach. In D. Rose \& C. Acevedo (Eds.), Reading to learn, reading the world: How genre-based literacy pedagogy is democratizing education. Equinox.

Kartika-Ningsih, H. \& Gunawan, W. (2019). Recontextualisation of genre-based pedagogy: The case of Indonesian EFL classrooms. Indonesian Journal of Applied Linguistics, 9(2), 335-347. https://ejournal.upi.edu/index.php/IJAL/article/view/20231

Kartika-Ningsih, H. \& Rose, D. (2018). Language shift: analysing language use in multilingual classroom interactions. Functional Linguistics, 5(1), 9. https:// doi.org/10.1186/s40554-018-0061-0

Lucas, A. M., McEwan, P. J., Ngware, M., \& Oketch, M. (2014). Improving early-grade literacy in East Africa: Experimental evidence from Kenya and Uganda. Journal of Policy Analysis and Management, 33(4), 950-976. https://doi.org/10.1002/pam.21782

Martin, J. R. (1992). English text: System and structure. John Benjamins Publishing.

Martin, J. R. (2000). Grammar meets genre: Reflections on the 'Sydney School'. Arts: The Journal of the Sydney University Arts Association, 22, 47-95.

Martin, J. R. (2010). Semantic variation: Modelling realisation, instantiation and individuation in social semiosis. In M. Bednarek \& J. R. Martin (Eds.), New discourse on language: Functional perspectives on multimodality, identity, and affliation (pp. 1-34). Continuum.

Martin, J. R. \& Rose, D. (2007). Working with discourse: Meaning beyond the clause. Continuum. 
Martin, J. R. \& Rose, D. (2008). Genre relations: Mapping culture. Equinox.

Millin, T. (2011). Scaffolding academic literacy with undergraduate social science students at the University of KwaZulu-Natal using the Reading to Learn intervention strategy: An evaluative study. (M. Sc. Dissertation), The University of Edinburgh Moray House School of Education, UK.

Nation, I. S. P. \& Meara, P. (2010). Vocabulary. In N. Schmitt (Ed.), An introduction to applied linguistics. (pp. 34-52). Hodder Education.

Nuthall, G. (2005). The cultural myths and realities of classroom teaching and learning: A personal journey. Teachers College Record, 107(5),895-934.https:// doi.org/10.1111/j.1467-9620.2005.00498.x

Purser, E., Dreyfus, S. \& Jones, P. (2020). Big ideas \& sharp focus: Researching and developing students' academic writing across the disciplines. Journal of English for Academic Purposes, 43, article 100807. https://doi.org/10.1016/j.jeap.2019.100807

Ramírez, A. (2018). Paraphrastic academic writing: Entry point for first generation advanced bilingual college students. In R. Harman (Ed.), Bilingual learners and social equity: Critical approaches to systemic functional linguistics (Educational Linguistics series, vol. 33, pp. 179-198). Springer. https://doi. org/10.1007/978-3-319-60953-9_9

Rose, D. (2018). Pedagogic register analysis: Mapping choices in teaching and learning. Functional Linguistics. 5, article 3. https://doi.org/10.1186/ s40554-018-0053-0

Rose, D. (2020a). Building a pedagogic metalanguage I: Curriculum genres and building a pedagogic metalanguage II: Knowledge genres. In J. R. Martin, K.
Maton, \& Y. J. Doran (Eds.), Accessing academic discourse: Systemic functional linguistics and legitimation code theory (pp. 236-302). Taylor \& Francis.

Rose, D. (2020b). Reading to Learn: Accelerating learning and closing the gap (Teacher training books and DVDs). Reading to Learn [website]. http://www. readingtolearn.com.au

Rose, D. (2020c). Designing pedagogic registers: Reading to Learn. In D. Caldwell, J. Knox, \& J. R. Martin (Eds.), Developing theory: $A$ handbook in appliable linguistics and semiotics. Bloomsbury.

Rose, D. \& Martin, J. R. (2012). Learning to write, reading to learn: Genre, knowledge and pedagogy in the Sydney School. Equinox.

Rothery, J. \& Stenglin, M. (1994). Exploring literacy in school English (write it right, resources for literacy and learning). Sydney Metropolitan East Disadvantaged Schools Program.

Sinclair, J. \& Coulthard, M. (1975). Towards an analysis of discourse: The English used by teachers and pupils. Oxford University Press.

Shum, M. S. K., Tai, C. P., \& Shi, D. (2018). Using 'Reading to Learn' (R2L) pedagogy to teach discussion genre to non-Chinese-speaking students in Hong Kong. International Journal of Bilingual Education and Bilingualism, 21(2), 237-247, https://doi.org/10.108 $0 / 13670050.2016 .1159653$

Tribble, C. (2001). Small corpora and teaching writing. In M. Ghadessy, A. Henry, \& R. L. Roseberry (Eds.), Small corpus studies and ELT: Theory and practice (pp. 381-408). John Benjamins.

Webb, S. \& Nation, P. (2017). How vocabulary is learned. Oxford University Press.

How to cite this article: Kartika-Ningsih, H. \& Rose, D. (2021). Intermodality and multilingual reinstantiation: Joint construction in bilingual genre pedagogy. Íkala, Revista de Lenguaje y Cultura, 26(1), 185-205. https://doi.org/10.17533/udea.ikala.v26n01a07 